\title{
Divergent Opinions Regarding Appointment of Academics to Judicial Offices in Nigeria: A Socio-Legal Approach
}

\author{
Musa Adamu Aliyu \\ Nasiru Adamu Aliyu
}

\begin{abstract}
Competence of academics to become judges has attracted divergent opinions among legal scholars. Intellectually academics have been conducting researches and disseminating the findings of the works in journals. Outside the four walls of the universities, the scholars are helping courts to appreciate difficult legal issues by filing scholars' brief. They appear before the courts as friends or amici curiae. In the United States, it is a tradition to appoint academics as judges, and there is similar practice in various parts of the world. Nigeria is one of the countries where academics were elevated to become judicial officers or judges of Superior Courts. Late Justice Teslim Elias was an academic appointed as a judicial officer. There are opinions for and against appointment of members of the academia into judicial offices. Proponents of the appointment believe that academics are suitable to be appointed as judges by virtue of their knowledge. On the other hand, those against such appointment are of the view that the academics lack practical experience in the courtroom. This reason makes them unqualified to be appointed judges. This paper has adopted a socio-legal research approach to understand the perspectives for and against appointing academics as judges. Nine members of the legal profession have been interviewed and majority of them have supported the appointment.
\end{abstract}

Keywords: Academics; courts; judicial offices; Nigeria; opinion; private legal practitioners

\section{INTRODUCTION}

Members of academia are important personalities in the society. They are persons with intellectual capacities to conduct researches and disseminate important research findings for the development of the general public. One area where the academics have been contributing is in assisting court to appreciate complex legal issues as friends of the court. That is, the practice of amici curiae, which is well established in the United States of America. It is a practice in the United States that academics are being appointed judges. In other parts of the globe there are members of the academia serving as judges in various courts. Nigeria is among the countries where academics had been appointed judges. The first academic that was appointed to judicial office in Nigeria was late Justice Teslim Elias. Justices such as Niki Tobi (retired), Justice of the Supreme Court, Justice Nura Sagir Umar (Chief Judge of Kano State), Justice Muhammad Kabir Dabo of the Kaduna State High Court of Justice and recently Justice Mohammed Musa Kaugama of the Jigawa State High Court for instance, attest the quality of justices and judges appointed from the academia.

Appointment of the academics as judges has received divergent opinions. Some legal experts are of the view that members of the academia are competent to occupy judicial offices as such they should be appointed to the exalted offices. Equally, some legal scholars are not in support of appointing academics as judges. To them academics do not have the requisite practical experience to become judges. This paper has studied the views for and against appointment of the academics as judicial officers in Nigeria. The research is socio-legal and semistructured interview was conducted in generating the opinions from nine members of the legal profession.

\section{LITERATURE REVIEW}

Academics are important in imparting knowledge through teaching, research and other responsibilities. ${ }^{1}$ One of the other tasks of the academic staff is that law professors have been appearing in courts as amici curiae to support parties in suits before courts. ${ }^{2}$ The professors being experts in specific areas of law are able to give well-versed analysis of pressing legal questions from a relatively impartial perspectives. ${ }^{3}$ Intellectual contributions of the senior legal academics has been considered helpful by three apex court justices in the United States. ${ }^{4}$ Professors of law have been participating in litigation before courts as amici curiae. In discharging the legal task, the law professors seem to like to collaborate with law firms in preparing the scholars' briefs. ${ }^{5}$ The Professors in 
the United States have for a long period of time being appointed as judges. ${ }^{6}$ In other parts of the world academics have also been appointed judges in various courts. The same practice applies in Nigeria, members of the academics are allowed to practice law in courts once they have the requisite professional qualifications provided in the Constitution and procedural rules for the appointment of superior court judges. ${ }^{7}$ What is required for an academic to be appointed judicial officer is for such person to present evidence of "Credible record of teaching law, legal research in a reputable University and publication of legal works..." Based on the above criteria legal academics have been appointed judicial officers in Nigeria. ${ }^{9}$ In England a former Professor of English Law from Cambridge University, Rouse Ball is believed to be the first academic to secure appointment as a judge to the High Court bench from the academia. ${ }^{10}$ Appointing academics as judges attract mix reactions. For the advocates of the appointment "...judges and academics are vessels in the same fleet, sailing together, working in collaboration to reach the same destination - the principled development of the law. There is no good reason why judges should not be drawn from the ranks of academics." ${ }^{11}$ Among the significance in appointing outstanding members of the academia, there is advantage of promoting institutional diversity and interdisciplinary approaches in law and justice. ${ }^{12}$ In supporting appointment of the academics to judicial offices, a proponent of the view had cited examples of distinguished academics who served in various courts across the world. ${ }^{13}$ On the other hand, those against appointment of academics as judges argued that members of the academia lack practical experience to handle litigations. ${ }^{14}$

\section{RESEARCH METHOD AND DATA}

This study has adopted Socio-Legal research methods using a qualitative approach. Legal research method, which is generally doctrinal, is not sufficient to explain the different opinions about the suitability of appointing academics as Superior Judges in Nigeria. There is paucity of literature in the area in Nigeria. Consequently, semi-structured interviews with stakeholders within the legal profession in Nigeria were conducted. The purposive sampling technique was adopted in the selection of the research participants. This is because the purposive sampling technique is the core sampling method for qualitative research such as the present research. ${ }^{15}$ The technique assisted the researchers in selecting only participants with the requisite information on the phenomenon of research. ${ }^{16}$ The demographic characteristics of the participants can be classified into two - legal practitioners that are retired judicial officers and lawyers that are not judicial officers. Participant 1 is an academic staff teaching law in the university. Participants 2 and 3 were State Director of Public Prosecution and State Attorney General respectively. Participants 4 and 5 are private legal practitioners and had served as members of judicial advisory bodies. Participants 6 and 7 are private legal practitioners that are in active legal practice. Last but not the least are participants 8 and 9 they were judicial officers. Participant 9 was Chairman of a State judicial advisory body; he also served as member of the recommendation body for the appointment of judicial officers and was a State Chief Judge.

TABLE 1. List of Participants and their demographic characteristics

\begin{tabular}{cll}
\hline SN & Participants & Participants' Demographic Characteristic \\
\hline 1. & Participant 1 (P1) & Academic Staff, University Lecturer \\
2. & Participant 2 (P2) & State Director Public Prosecution \\
3. & Participant 3 (P3) & State Attorney General \\
4. & Participant 4 (P4) & Private Legal Practitioner \& Member Judicial Advisory Body \\
5. & Participant 5 (P5) & Private Legal Practitioner \& Member Judicial Advisory Body \\
6. & Participant 6 (P6) & Active Private Legal Practitioner \\
7. & Participant 7 (P7) & Active Private Legal Practitioner \\
8. & Participant 8 (P8) & Serving Judicial Officer \\
9. & Participant 9 (P9) & Serving Judicial Officer and Chairman of Judicial Advisory Body \\
\hline
\end{tabular}


TABLE 2. List of Participants and their demographic characteristics who supports appointment of Academics as Judicial Officers of Court of First instance

\begin{tabular}{cll}
\hline SN & Participants & Participants' Demographic Characteristic \\
\hline 1. & Participant 1 (P1) & Academic Staff, University Lecturer \\
2. & Participant 4 (P4) & Private Legal Practitioner \& Member Judicial Advisory Body \\
3. & Participant 5 (P5) & Private Legal Practitioner \& Member Judicial Advisory Body \\
4. & Participant 7 (P7) & Active Private Legal Practitioner \\
5. & Participant 8 (P8) & Serving Judicial Officer \\
6. & Participant 9 (P9) & Serving Judicial Officer and Chairman of Judicial Advisory Body \\
\hline
\end{tabular}

TABLE 3. List of Participants and their demographic characteristics who do not support appointment of Academics to any Judicial Offices

\begin{tabular}{cll}
\hline SN & Participants & Participants' Demographic Characteristic \\
\hline 1. & Participant 2(P2) & State Director Public Prosecution \\
2. & Participant 3 (P3) & State Attorney General \\
3. & Participant 6 (P6) & Active Private Legal Practitioner \\
\hline
\end{tabular}

TABLE 4. List of Participants and their demographic characteristics who do not support appointment of Academics to Appellate Courts directly from University

\begin{tabular}{rll}
\hline SN & Participants & Participants’ Demographic Characteristic \\
\hline 1. & Participant 4 (P4) & Private Legal Practitioner \& Member Judicial Advisory Body \\
2. & Participant 5 (P5) & Private Legal Practitioner \& Member Judicial Advisory Body \\
3. & Participant 8 (P8) & Serving Judicial Officer \\
4. & Participant 9 (P9) & Serving Judicial Officer and Chairman of Judicial Advisory Body \\
\hline
\end{tabular}

TABLE 5. List of Participants and their demographic characteristics who supports appointment of Academics to Appellate Courts directly from University

\begin{tabular}{cll}
\hline SN & Participants & Participants' Demographic Characteristic \\
\hline 1. & Participant 1 (P1) & Academic Staff, University Lecturer \\
2. & Participant 7 (P7) & Active Private Legal Practitioner \\
\hline
\end{tabular}

The participants were asked the same set of questions. The responses from the participants during the interviews were quite helpful. Answers from the interviews, laws and articles are data used in explaining the opinions for and against the appointment of members of the academia as Judicial Officers in Nigeria.

\section{FINDINGS AND DISCUSSIONS}

Judicial Officers in Nigeria are persons holding judicial offices of superior courts listed in section 318 of the Constitution of the Federal Republic of Nigeria 1999. The judges consist of legal practitioners and non-lawyers with requisite qualifications provided in the Constitution. Such judges could be judicial officers in Courts with original jurisdiction or Appellate powers. See Chapter VII, Part I of the Constitution. With the exception of judicial officers to decide Islamic personal law and Customary law at the Sharia Court of Appeal, Customary
Court of Appeal and Court of Appeal, there is no Constitutional requirement that such persons must have practical experience (Sections 237(2),(b), 247(1), (a) \& (b), 261(3), (a),(b), (i) \& (ii), 266(3), (a) \& (b), 276(3),(a),(b),(i) \& (ii) and 281 (3), (a) \& (b) of the Constitution).

However, there are additional criteria stipulated by a subsidiary legislation that candidates to judicial offices must have. Such requirements include that the legal practitioners must have practical experience in court room trial as Private Legal practitioners or as Government lawyers. Apart from the fact that those in the academics must have "credible record of teaching law, legal research in a reputable University and publication of legal works," Professors in Nigeria do also practice; as such have the practical experience in litigation. (Rule 4(4), (b) \& (d) (Extant Revised NJC Guidelines \& Procedural Rules for the Appointment of Judicial Officers of All Superior Courts of Record in Nigeria, 2014). 
The perception of members of the legal profession in Nigeria about appointing members of the academia as judicial officers is divergent. Results from the data showed the different views about appointing academics as judicial officers in Nigeria. There is a precedent of appointing members of the academia in Nigeria. Professor Teslim Elias was appointed a justice of the Supreme Court. Subsequently he became Chief Justice of Nigeria ${ }^{17}$ and later he was appointed President of the International Court of Justice (O'Dell, 2015). The advantage of appointing academics into judicial offices is that "they will bring their learning and scholarship to bear on their judgments and complement the efforts of those of their peers on the bench who do not have academic background". ${ }^{18} \mathrm{P} 9$ has a similar opinion in supporting appointment of academics as judicial officers:

"As for the appointment of those in the academia as Judicial Officers, I support the idea. Considering private legal practitioners for such appointment qualifies the academic competence... The academics have higher educational qualifications which give them an added advantage of appreciating complex legal issues...There are excellent members of the academia who are serving Judges and they are doing very well. We had (Justices) Elias and Niki Tobi who were erudite Justices. Please observe Judges from the academia and ask yourself this question: Are they bad judges?"

P7, a private legal practitioner has answered the above poser. Appointment of the academics into judicial offices, in the opinion of the lawyer, is good. His view is that there is a proof that some of them were excellent on the bench. Also, currently, in Nigeria there is a justice of the Supreme Court who came from the academia that has been making great contribution. According to P7:

"Some of the best judges we had are those who moved from the academia to the bench. Look at Niki Tobi: he was a Professor of Law. Look at this current wave in the Supreme Court, Justice Nweze is also from the academia. He enriches the law. So, you allow for cross breeding but the emphasis that the individual should be understudied for a longer period than they are doing now."

In this study, two of the participants $\mathrm{P} 4$ and P5 who served in the bodies that have power to advice recommendation body on the persons to be appointed judicial officers are in support of appointing members of the academia into judicial offices. They have agreed that the academics are knowledgeable enough to be appointed into the offices. P1 and P8 have the same opinion that the academics are qualified to be appointed to judicial offices. According toP1 and P8, it is a good idea to appoint the academics as judicial officers as they are capable of discharging judicial functions.

Participants 2, 3 and 6 have strong contrary view, to them academics are not competent for appointment as judicial officers in any courts. According them, the academics do not have the requisite practical experience to handle cases as umpires. In opposing the idea, P3 begun his disapproval with a query:

"Why should you give an opportunity to somebody who is $100 \%$ academic? a researcher, somebody who delivers lectures to students! I think if you are talking of practice, you are talking of rules of court, application of the rules; experience from that rules. Understanding the rules will take you a number of years for you to appreciate the rules and apply them."

Another area with respect to the appointment academics to judicial offices is what should be their entry point? Should they be appointed directly to the Court of Appeal and Supreme Court from the university? P1 and P7 have answered the latter question in the affirmative.

However, other participants (P2, P3, P4, P5, P6, P8 and P9) who supported the appointment of academics to judicial offices have reservation on appointing them directly from the university to the Court of Appeal or Supreme Court. Their caveat is that such appointment should be restricted to judicial offices in court of first instance. According to them selection or appointment of Court of Appeal and Supreme Court justices should be made from among serving judicial officers of the superior court of records.

From the responses P6 and P7 even though both have the same background, their response differs on the competence of academics for appointment as judicial officers. This is interesting and demonstrates the perspective of the participants. The divergence may be due to personal experiences or the prejudice against the appointment of academics as opposed to core legal practitioners.

The overall finding shows that seven out of the nine participants in this study are of the opinion that members of the academia should be part of the persons qualified for appointment as judicial officers in court of first instance Nigeria. This represents eighty percent of the participants, acceptance of the appointments of academics as judicial officers. However, two out of the seven participants which represent $28 \%$ of the participants, are of the opinion that members of the academia are competent to even be appointed directly to the appellate courts from university. 


\section{CONCLUSION}

The paper has provided discussions on the suitability of appointing academics as judges. These persons have skills in conducting research and dissemination of knowledge. Appointing members of the academia as judges has generated divergent intellectual discussions. The proponents of the appointment are of the opinion that academics are competent to occupy the offices by virtue of their knowledge. On the other hand, persons that are not in support of the appointment have the views that academics lack practical experience to handle cases in courts. In the United States Professors of law have been participating in litigation before courts as amici curiae. Professors in the United States have for a long period of time being appointed as judges. In other parts of the world academics have been appointed judges in various courts. Nigeria is one of such countries; late Justice Teslim Elias was a Professor of law in the University of Lagos before he was appointed justice of the Supreme Court and later he became Chief Justice of Nigeria. Professor Elias was subsequently appointed justice of the International Court of Justice. He also served as President of the International Court of Justice. As a conclusion, this paper found that the opinions on appointing academics as judicial officers are divergent. Majority of the participants interviewed have supported such appointment. The only caveat they have is that the academics should start their judicial career from lower courts and should not directly secure appointments from university directly to the Supreme Court or Court of Appeal.

\section{NOTES}

1 Yaacob, Nurli; Yeon, Asmah Laili and Abdul Rahman, R., Workload of Academic Staff in Malaysian Public University: Perspectives of Top Management. In A. H. M. Abdul Rahim, Asmar; Rahman, Aspalella A.; Abdul Wahab, Harlida; Yaacob, Nurli; Mohamad, Ani Munirah; Mohd and Arshad (Ed.), ILC 2017 - 9TH UUM International Legal Conference 2017 (pp. 873-883), Sintok Darul Aman: Future Academy, 2017.

2 Fallon, J. R. H., Scholars'Briefs and the Vocation of a Law Professor, Retrieved July 21, 2019, from https://doi. org/10.1093/jla/las002.

3 Sandstrom, S. L., An Empeirical Study of Amici Curiae in Federal Court: A Fine Balance of Access, Efficiency, and Advertisarialism, Review of Litigation, 2008, pg 669-712.

4 Ibid.

5 Fallon, J. R. H., Scholars' Briefs and the Vocation of a Law Professor, Retrieved July 21, 2019, from https://doi. org/10.1093/jla/las002.
6 Posner, R., The Judiciary and the Academy: A Fraught Relationship, University of Queensland Law Journal, 29(1), 2010, pg 13.

7 Rule 3(6) of the Extant Revised NJC Guidelines and Procedural Rules for the Appointment of Judicial officers of All Superior Court in Nigeria, 2014.

8 Rule 4(4),(d) of the Extant Revised NJC Guidelines and Procedural Rules for the Appointment of Judicial officers of All Superior Court in Nigeria, 2014.

9 https://www.highcourtkd.gov.ng, Ikhilae, E. NJC names 69 new judges, courts, heads of courts, The Nation, 2021, Retrieved from https://thenationonline.net

10 Feenan, D., Judicial Appointments in Ireland in Comparative Perspective, Judicial Institute Journal, 1(34), 2008, pg 45.

11 O'Dell, D. E., Why should legal academics not be judges? Retrieved July 21, 2019, from cearta.ie

12 Kumar, C Raj and Gautam, K., The Judiciary Must Try to Diversify the Institution. Hindustantimes. Retrieved 9 January 2019, from www.hindustantimes.com

13 O'Dell, D. E., Why should legal academics not be judges? Retrieved July 21, 2019, from cearta.ie

14 Denham, The Hon. Mrs. Justice Susan; Kearns, The Hon. Mr. Justice Nicholas J.; Donnell, The Hon. Mr. Justice Donal; Kelly, The Hon. Mr. Justice Peter; Gilligan, The Hon. Mr. Justice Paul; Groarke, The Hon. Mr. Justice Raymond; Linnanne; Her Honour Judge J, J. C., Judicial Appointment Review Committee Preliminary Submission to the Department of Justice and Equality's Public Consultation on the Judicial Appointments Process, 2014.

15 Usman, Dahiru Jafaru, Nurli Yaacob, and Aspalella A. Rahman, An inquiry on the affordability of legal services and the appropriateness of the regular courts for consumer redress in Nigeria, Beijing L. Rev. 7 (2016): 83.

16 Usman, Dahiru Jafaru, Nurli Yaacob, and Aspalella A. Rahman, Lack of consumer awareness: A major challenge for electricity consumer protection in Nigeria, Asian Social Science 11, no. 24 (2015): 240.

17 Olofintila, T., Why more lecturers are needed on the Bench, The Nation, 2013, Retrieved from https:// thenationonlineng.net

18 Ibid.

\section{REFERENCES}

Constitution of the Federal Republic of Nigeria (As Amended). 1999.

Denham, The Hon. Mrs. Justice Susan; Kearns, The Hon. Mr. Justice Nicholas J.; Donnell, The Hon. Mr. Justice Donal; Kelly, The Hon. Mr. Justice Peter; Gilligan, The Hon. Mr. Justice Paul; Groarke, The Hon. Mr. Justice Raymond; Linnanne; Her Honour Judge J, J. C. 2014. Judicial Appointment Review Committee Preliminary Submission to the Department of Justice and Equality's Public Consultation on the Judicial Appointments Process.

Extant Revised NJC Guidelines \& Procedural Rules for the Appointment of Judicial Officers of All Superiror Courts of Record in Nigeria. 2014.

Fallon, J. R. H. 2012. Scholars' Briefs and the Vocation of a Law Professor. https://doi.org/10.1093/jla/las002 (accessed 21 July 2018) 
Feenan, D. 2008. Judicial Appointments in Ireland in Comparative Perspective. Judicial Institute Journal 1(34): 45.

Kumar, C Raj and Gautam, K. 2019, January 9. The Judiciary Must Try to Diversify the Institution. Hindustantimes. www.hindustantimes.com (accessed July 8, 2019)

O’Dell, D. E. 2015. Why Should Legal Academics not be Judges? cearta.ie (accessed July 21, 2019)

Olofintila, T. 2013. Why more Lecturers are needed on the Bench. The Nation. Retrieved from https:// thenationonlineng.net(accessed 8 July 2019).

Posner, R. 2010. The judiciary and the academy: A fraught relationship. University of Queensland Law Journal 29(1): 13.

Sandstrom, S. L. 2008. An empirical study of Amici Curiae in Federal Court: A fine balance of access, efficiency, and advertisarialism. Review of Litigation: 669-712.

Usman, Dahiru Jafaru, Nurli Yaacob, and Aspalella A. Rahman. 2016. An inquiry on the affordability of legal services and the appropriateness of the regular courts for consumer redress in Nigeria. Beijing L. Rev. 7: 83-94.

Usman, Dahiru Jafaru, Nurli Yaacob, and Aspalella A. Rahman. 2015. Lack of consumer awareness: A major challenge for electricity consumer protection in Nigeria, Asian Social Science 11(24): 240-251.
Yaacob, Nurli; Yeon, AsmahLaili and Abdul Rahman, R. 2017. Workload of academic staff in Malaysian public university: Perspectives of top management. In $I L C$ 2017 - 9 TH UUM International Legal Conference 2017, edited by A. H. M. Abdul Rahim, Asmar; Rahman, Aspalella A.; Abdul Wahab, Harlida; Yaacob, Nurli; Mohamad, AniMunirah; Mohd and Arshad, 873-883. Sintok Darul Aman: Future Academy.

Yaqin, A. 2007. Legal Research and Writing. Selangor: Lexis Nexis.

Musa Adamu Aliyu

Office of Attorney General/Commissioner for Justice Jigawa State Ministry of Justice

Nigeria

Email: msaliyu1977@gmail.com

Nasiru Adamu Aliyu

Department of Public Law

Faculty of Law

Bayero University, Kano

Nigeria

Email: nasiraliyu@gmail.com 